\title{
Global Value Chains (GVC) Pada Komoditi Primer Dan Manufaktur: Studi ASEAN 6
}

\author{
Steven Raja Ingot' ${ }^{1}$ Kiki Verico² \\ 1) Badan Pengkajian dan Pengembangan Perdagangan, Kementerian Perdagangan \\ 2) Fakultas Ekonomi dan Bisnis, Universitas Indonesia \\ Email : sri.bako@gmail.com \\ HP: +62818850913
}

\begin{abstract}
Abstrak
Semakin rendahnya biaya perdagangan antar negara menyebabkan peningkatan kegiatan perdagangan dengan skema Global Value Chains (GVC) yang terbukti memberikan banyak manfaat bagi negara antara lain percepatan industrialisasi, transfer teknologi, penyerapan tenaga kerja dan peningkatan nilai tambah industri. Partisipasi dalam GVC terdiri dari dua komponen yakni forward participation dan backward participation dimana keduanya memiliki karakteristik yang berbeda. Penelitian ini bertujuan untuk mengidentifikasi apakah ekspor komoditi primer (karet dan CPO) negara ASEAN 6 berhubungan dengan partisipasi GVC forward dan ekspor komoditi manufaktur (elektronik dan otomotif) berhubungan dengan GVC backward serta mengeksplorasi faktor-faktor yang dapat mendorong partisipasi GVC. Studi ini menggunakan data panel dinamis dengan metode GMM dan menemukan bahwa ekspor komoditi primer berhubungan dengan GVC forward kecuali untuk produk CPO sedangkan ekspor komoditi manufaktur berhubungan dengan GVC backward. Peningkatan GDP berpengaruh negatif terhadap partisipasi GVC sehingga peningkatan produktivitas sangat diperlukan untuk mendorong partisipasi, sedangkan FDI yang masuk ke wilayah ASEAN 6 diindikasikan lebih kepada resource dan market seeking bukan network seeking. kualitas infrastuktur berhubungan positif dengan forward participation karena kualitas produk hasil sumber daya alam berpengaruh dari kualitas infrastruktur. Kualitas pembiayaan dalam negeri dan kualitas institusi perlindungan hukum atas hak kekayaan intelektual berhubungan dengan backward participation. Pemodalan juga sangat dibutuhkan oleh industri untuk mendukung kegiatan perdagangannya serta kualitas perlindungan atas hak kekayaan intelektual juga berhubungan positif dalam mendorong backward participation.
\end{abstract}

Keywords: Partisipasi Global Value Chains (GVC); Trade in Value added; ASEAN 6; komoditi primer; komoditi manufaktur.

\begin{abstract}
Low trading costs between countries have led to increased trade activities using the Global Value Chains (GVC) scheme which has proven to provide many benefits for countries, including accelerated industrialization, technology transfer, employment, and increased industrial valueadded. Participation in the GVC consists of two components, namely forward participation and backward participation which have different characters. This study aims to identify whether exports of primary commodities (rubber and CPO) in ASEAN 6 countries are related to forward GVC participation and export of manufactured commodities (electronics and automotive) are related to backward GVCs and lastly explore factors that can encourage GVC participation. This study uses dynamic panel data using the GMM method and finds that primary commodity exports are related to forward GVC except for CPO products while manufactured commodity exports are
\end{abstract}


related to backward GVC. An increase in GDP has a negative relation to GVC participation so that increased productivity is needed to encourage participation, while FDI that enters the ASEAN 6 region is indicated more towards finding resources and markets, not searching for networks. The quality of infrastructure has a positive relationship with forward participation because it affects the quality of the natural resource products. The quality of domestic financing and institutions for protecting intellectual property rights is associated with backward participation. The national industry is also needed domestic finance to support its trading activities and the intellectual property rights protection is also positively related to encouraging backward participation.

Keywords: Global Value Chains (GVC) Participation; Trade-in Value Added; ASEAN 6, primary commodities, manufactured commodities.

(C) 2020 Pusdiklat Perdagangan. All rights reserved

\section{PENDAHULUAN \\ Latar Belakang}

Perkembangan teknologi informasi dan peningkatan konektivitas logistik yang terjadi di abad 21 ini telah mendorong negara untuk mengembangkan teknik dalam perdagangan internasional. Saat ini suatu negara dapat terlibat dalam perdagangan internasional tanpa harus memproduksi barang dari hulu ke hilir secara mandiri dengan melakukan spesialisasi dalam suatu tahapan produksi barang yang dikenal dengan istilah Global Value Chain - GVC (Baldwin, 2016). Skema GVC memiliki beberapa keuntungan antara lain dapat mendorong kemajuan industri (Taglioni \& Winkler, 2016), berkorelasi positif terhadap produktifitas sektor manufaktur terutama di negara berkembang dan terbuka peluang untuk semakin berkembang pada aktifitas produksi yang memberi nilai tambah lebih tinggi (Pahl \& Timmer, 2020). Mayoritas negara di kawasan ASEAN adalah negara berkembang berlimpah sumber daya alam dengan karakteristik yang sama serta populasi besar dan terus bertumbuh, dimana saat ini populasinya lebih kurang 650 juta penduduk. ASEAN perlu terus meningkatkan perekonomiannya serta aktif membuka lapangan pekerjaan salah satu caranya adalah meningkatkan partisipasi aktif dalam GVC.

Penelitian ini bertujuan untuk mengidentifikasi apakah ekspor komoditi primer CPO dan Karet berhubungan dengan tingkat GVC forward participation negara ASEAN 6, mengidentifikasi apakah ekspor komoditi manufaktur elektronik dan otomotif berhubungan dengan tingkat GVC backward participation Negara ASEAN 6 dan mengeksplorasi faktor-faktor yang dapat mendorong GVC baik forward maupun backward participation.

Dasar pembagian antara backward dan forward adalah penelitian ADB pada tahun 2019 yang menyatakan bahwa jika persentase forward participation dalam suatu negara lebih tinggi dibandingkan persentase backward participation negara tersebut cenderung melakukan ekspor produk upstream (kegiatan menghasilkan produk yang digunakan sebagai bahan baku), sedangkan jika negara memiliki persentase backward participation yang lebih tinggi dibandingkan dengan forward participation maka secara umum dapat disimpulkan bahwa negara tersebut banyak melakukan aktivitas perdagangan yang melibatkan kegiatan perdagangan downstream (kegiatan pengolahan dari bahan setengah jadi menjadi bahan jadi) (ADB, 2019). Sehingga bahan mentah identik dengan forward participation sedangkan barang intermediate identik pada backward participation.

Temuan dari penelitian ini juga dapat dimanfaatkan oleh masing-masing negara anggota ASEAN termasuk Indonesia yang merupakan negara terbesar di kawasan untuk terus bertumbuh dalam partisipasi GVC. 


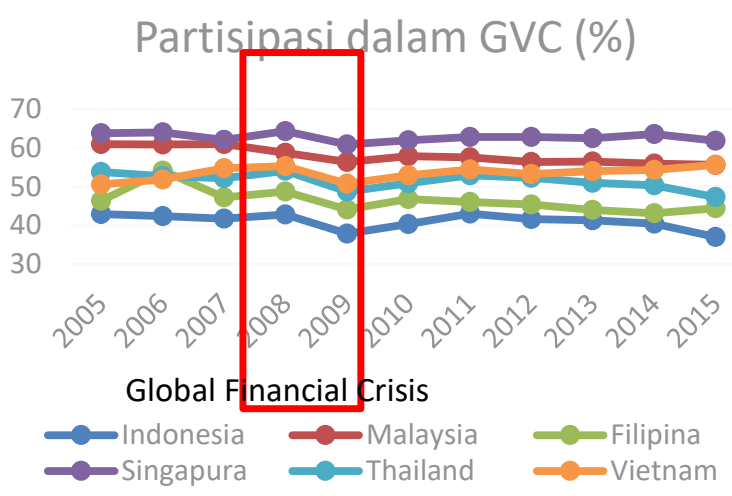

Sumber: OECD TiVA edisi 2018, Diolah (2020)

\section{Gambar 1. Tingkat Partisipasi GVC 6 negara ASEAN}

Berdasarkan gambar 1 terlihat bahwa setiap negara memiliki perbedaan tingkat partisipasi GVC hal ini dipengaruhi dari struktur industri dan ukuran negara (Kowalski et al., 2015) namun bagaimana suatu negara dapat terus meningkatkan porsi perdagangannya dengan skema GVC. Singapura memimpin dalam keterlibatan dalam GVC dengan nilai yang relatif stabil diatas $60 \%$, Filipina relatif stabil pada level 40\%. Tren yang positif ditunjukkan oleh Vietnam dimana persentase partisipasi GVC konsisten mengalami pertumbuhan pada periode pengamatan.

Thailand, Singapura, Malaysia dan Indonesia mengalami penurunan namun partisipasi Indonesia dalam GVC masih relatif rendah dibandingkan dengan negara tetangga. Partisipasi GVC Indonesia terus mengalami penurunan dari 43\% pada tahun 2005 menjadi $37 \%$ pada tahun 2015. Global Financial Crisis pada tahun 2008 turut berdampak pada perdagangan dengan skema GVC, semua negara mengalami penurunan signifikan dalam GVC dan kembali mengalami perbaikan.

Partisipasi dalam GVC terdiri dari penjumlahan dari sisi suatu negara sebagai pembeli (backward participation) dan penjual (forward participation) (Taglioni \& Winkler, 2016). Secara garis besar indikator tersebut dapat digunakan untuk menggambarkan sektor ekonomi yang mendorong GVC dalam suatu negara. Jika persentase forward participation dalam suatu negara lebih tinggi dibandingkan persentase backward participation negara tersebut cenderung melakukan ekspor produk upstream (kegiatan menghasilkan produk yang digunakan sebagai bahan baku), sedangkan jika negara memiliki persentasi backward participation yang lebih tinggi dibandingkan dengan forward participation maka secara umum dapat disimpulkan bahwa negara tersebut banyak melakukan aktivitas perdagangan yang melibatkan kegiatan perdagangan downstream (kegiatan pengolahan dari bahan setengah jadi menjadi bahan jadi) (ADB, 2019).

Berdasarkan gambar 2 dapat kita bandingkan secara garis besar sektor ekonomi negara, Singapura, Malaysia, Thailand dan Vietnam memiliki backward participation yang relatif tinggi dibandingkan dengan Filipina dan Indonesia. Indonesia berada di posisi rendah dengan tren yang menurun. Lebih lanjut jika dibandingkan dengan gambar 3 yakni forward participation Indonesia sangat menonjol dibandingkan dengan 6 negara di kawasan ASEAN lainnya namun mayoritas menunjukkan tren penurunan. Jika merujuk pada penelitian $A D B$, Indonesia memiliki tingkat forward participation lebih tinggi dibandingkan backward participation memberikan gambaran bahwa Indonesia banyak melakukan kegiatan perekonomian upstream yakni mayoritas berdagang bahan baku. Indonesia perlu mempertahankan forward participation namun di lain sisi meningkatkan backward participation sehingga teknologi industri dalam negeri semakin maju dan mampu memproduksi lebih banyak barang yang memiliki nilai tambah.

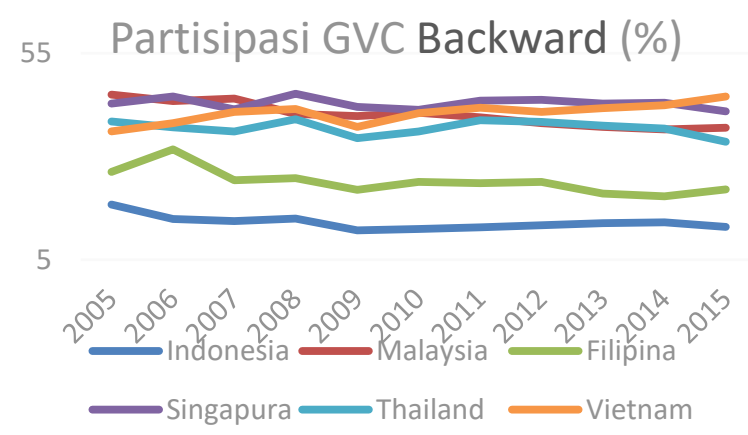

Sumber: OECD TiVA edisi 2018, Diolah (2020)

\section{Gambar 2. Tingkat Partisipasi GVC Backward 6 negara ASEAN}




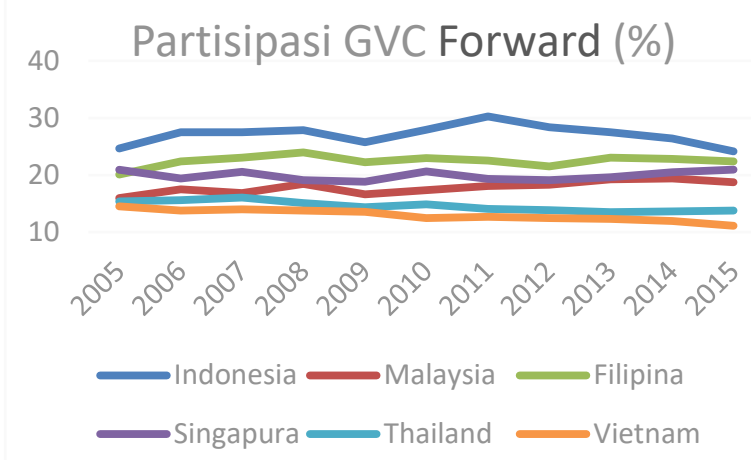

Sumber: OECD TiVA edisi 2018, Diolah (2020)

\section{Gambar 3. Tingkat Partisipasi GVC Forward 6 negara ASEAN}

Ketika suatu negara semakin terlibat dalam GVC banyak hal positif seperti yang sudah disampaikan sebelumnya, di sisi lain hal tersebut juga memberikan dampak negatif di masyarakat maupun secara politik seperti semakin tingginya impor yang dikhawatirkan berpotensi mencederai perkembangan industri nasional. Namun perlu dicatat bahwa dalam skema GVC peningkatan impor tersebut tidak selamanya buruk karena dalam GVC barang yang diimpor tersebut diolah dan di ekspor kembali sehingga secara makro jika suatu negara terlibat tinggi dalam GVC akan memberikan nilai tambah yang tinggi bagi industri.

Studi terkait faktor yang mempengaruhi partisipasi GVC banyak dilakukan dalam beberapa tahun terakhir dimana partisipasi dalam GVC dipengaruhi oleh non-policy factors, core trade and investment policy related factors dan other policy related factors (Kowalski et al., 2015), namun berbeda wilayah juga memiliki beberapa perbedaan faktor yang mendorong partisipasi dalam GVC. Arus investasi asing serta diversifikasi produk ekspor mendorong backward participation pada wilayah ECOWAS (Economic Community of West African States) (Tinta, 2017), sedangkan pada wilayah Uni Eropa pada umumnya lag partisipasi GVC, PDB perkapita serta pertumbuhan PDB memberikan dampak yang positif dan signifikan. Perbedaan terjadi jika dikelompokkan pada anggota baru Uni Eropa, penelitian dan pengembangan serta intensitas arus investasi asing mempengaruhi partisipasi
GVC sedangkan arus investasi asing tidak terlalu berpengaruh pada Uni Eropa secara keseluruhan (Kersan-Škabić, 2019). Penelitian tersebut menunjukkan bahwa faktor yang mendorong partisipasi GVC memiliki perbedaan pada tiap wilayah karena perbedaan struktur ekonomi, geografi dan tingkat kemajuan suatu wilayah.

Fokus pada penelitian ini adalah produk komoditi primer yakni karet dan CPO serta komoditi manufaktur yakni elektronik dan otomotif. Karet dan CPO dipilih untuk proksi produk primer karena negara di kawasan ASEAN merupakan eksportir utama untuk komoditi ini sedangkan untuk elektronik dan otomotif dipilih sebagai proksi komoditi manufaktur karena barang tersebut banyak diproduksi dalam skema GVC dan juga di ekspor oleh negara di kawasan ini.

Saat ini belum terdapat literatur studi empiris untuk menganalisis faktor - faktor yang mendorong partisipasi GVC dalam lingkup ASEAN 6 yakni Indonesia, Malaysia, Singapura, Thailand, Vietnam dan Filipina. Mengetahui apakah ekspor komoditi primer CPO dan Karet berhubungan dengan tingkat forward participation negara ASEAN 6. Mengetahui apakah ekspor komoditi manufaktur elektronik dan otomotif berhubungan dengan tingkat backward participation ASEAN 6 dan memberikan rekomendasi kebijakan yang dapat mendorong partisipasi GVC baik forward maupun backward participation.

Terdapat beberapa aspek yang menjadi kontribusi dari penelitian ini yakni menemukan faktor-faktor yang mempengaruhi partisipasi GVC ASEAN 6 sehingga dapat memberikan masukan kepada Pemerintah melalui instansi yang terkait untuk dapat menghasilkan kebijakan tepat guna mendorong partisipasi GVC ASEAN 6. Penelitian ini juga akan melakukan analisis Partisipasi GVC terhadap dua faktor pembentuknya yakni forward participation dan backward participation serta melihat hubungan ekspor komoditi primer terhadap forward participation dan manufaktur terhadap backward participation. Hasil dari penelitian empiris ini akan diharapkan dapat memberikan sumbangan akademis 
pada penelitian bidang GVC yang akan datang.

Penelitian ini terbatas pada 6 negara di kawasan ASEAN karena 6 negara tersebut menguasai $97 \%$ lebih nilai ekspor di ASEAN serta banyak variabel yang digunakan dalam penelitian ini belum mencakup data negara ASEAN diluar 6 negara tersebut. Sedangkan metode yang digunakan adalah dinamis panel data menggunakan generalised method of moments (GMM). GVC juga terkait dengan sektor jasa, namun cakupan penelitian ini dibatasi hanya pada sektor perdagangan barang komoditi primer (karet dan CPO) serta manufaktur (elektronik dan otomotif). Penelitian ini terbatas untuk melihat faktor yang mendorong partisipasi GVC baik forward dan backward serta tidak meneliti terkait percepatan industrialisasi dan mekanisme transfer teknologi melalui pemanfaatan GVC.

Penelitian ini dilakukan menggunakan periode tahun 2005-2015 karena data GVC dari OECD TiVA terbaru yakni edisi 2018 terbatas pada periode 2005 - 2015. Data terkait GVC masih memiliki jeda yang panjang karena dibangun berdasarkan data Inter Country Input-Output. Pada tahun 2020 terjadi pandemi yang tentu berdampak negatif terhadap perdagangan internasional termasuk GVC namun dikarenakan keterbatasan data, penelitian ini belum memasukkan dampak dari pandemi.

Penelitian ini terbagi atas lima bagian dimana Bagian I merupakan elaborasi latar belakang posisi partisipasi GVC negara di kawasan ASEAN 6 serta menunjukkan urgensi dari penelitian, Bagian II merupakan tinjauan pustaka terkait GVC, Bagian III elaborasi sumber data, jenis dan metode penelitian, Bagian IV memaparkan hasil uji empiris lalu bagian penutup yang mencakup kesimpulan, rekomendasi kebijakan dan saran untuk penelitian selanjutnya.

\section{TINJAUAN PUSTAKA}

Teori perdagangan internasional yang ditemukan pada abad 19 oleh David Ricardo tetap menjadi dasar pemikiran mengapa perdagangan internasional terjadi hingga abad 21 ini. Perkembangan dalam teknologi informatika dan transportasi ini menghasilkan konsep perdagangan dengan skema "unbundling" ala Baldwin (Baldwin, 2016). Tiga komponen biaya utama dalam perdagangan menurut Baldwin yang pertama adalah biaya perdagangan atau cost of moving goods yang kedua adalah biaya komunikasi atau cost of moving ideas yang terakhir adalah biaya tatap muka atau cost of moving people. Konsep "unbundling" Baldwin menyebutkan bahwa dalam tiap perkembangan teknologi informasi dan transportasi menghilangkan tiga penghambat utama dalam perdagangan tersebut secara bertahap.

Sebelum adanya globalisasi, ketiga komponen biaya tersebut sangat tinggi menyebabkan perdagangan internasional sangat mahal hingga tiap negara memenuhi kebutuhannya sendiri. Setelah adanya penemuan mesin vap dan terjadinya revolusi industri pertama komponen biaya perdagangan berhasil diturunkan sehingga terjadi "unbundling" pertama yakni dimana dahulu produksi dan konsumsi dilakukan dalam satu wilayah, sekarang produksi dapat dilakukan di wilayah A dan konsumsi dilakukan di wilayah B.

Lebih lanjut, memasuki era 1990 - 2015 pada tahap dua proses "unbundling" dimana pada tahap ini biaya terkait teknologi informasi dan komunikasi semakin rendah seiring dengan semakin murahnya biaya komunikasi seiring pertumbuhan pengguna internet. Ide dan inovasi yang pada tahap pertama terpusat pada industri di negara maju seiring dengan rendahnya biaya komunikasi lokasi produksi dapat berpindah ke negara berkembang yang biaya produksinya lebih murah. Sedangkan tahap terakhir proses "unbundling" adalah tahap dimana penetrasi internet semakin merata sehingga biaya perdagangan, komunikasi dan tatap muka rendah pekerjaan dapat dilakukan hingga tingkat perorangan antar negara.

Tiga tahap "unbundling" yang dikemukakan oleh Baldwin tersebut tidak dapat disamaratakan antar negara atau wilayah karena keunikan dari masing-masing wilayah seperti kondisi geografis, infrastruktur, sumber daya manusia, sistem perekonomian dan kebijakan yang dijalankan (Kimura, 2019). 


\section{Teori Global Value Chains (GVC)}

GVC didefinisikan sebagai tahapan dalam produksi suatu barang atau jasa yang dijual ke konsumen, dimana dalam tiap tahapannya terdapat peningkatan nilai (value) terdiri dari minimal dua tahap produksi pada negara yang berbeda. Negara dapat dikatakan berpartisipasi dalam GVC jika terlibat setidaknya 1 tahap dalam GVC (Antràs, 2020).

Perdagangan dengan GVC memiliki perbedaan dengan perdagangan tradisional dimana transaksinya hanya melibatkan dua negara yakni eksportir dan importir karena perdagangan GVC melewati perbatasan negara beberapa kali sehingga lebih sulit untuk mengukur perdagangan dalam rangka GVC. Usaha untuk melakukan pemetaan terhadap GVC telah dilakukan salah satunya studi kasus iPhone.

Jika dihitung menggunakan data ekspor impor tradisional yaitu nilai ekspor iPhone dari Tiongkok ke Amerika Serikat maka terdapat defisit neraca di sisi Amerika Serikat sebesar USD 1,9 Milyar, namun jika dihitung berdasarkan perdagangan nilai tambah maka defisit Amerika Serikat dengan Tiongkok hanya sebesar USD 73 juta. Hal tersebut terjadi karena komponen pembentuk iPhone tersebut banyak yang diimpor dari Jepang, Jerman maupun negara lain (Xing \& Detert, 2010).

Terbatasnya pemetaan perdagangan dengan nilai tambah atau GVC membuat data multicountry input output mulai banyak digunakan walaupun masih banyak kekurangannya. Konsep vertical specialization (Hummels et al., 2001) dikembangkan dengan studi lanjutan kasus ekspor Tiongkok menggunakan matriks input output dan membaginya jadi dua, sektor yang memproses barang ekspor dan satu lagi untuk keseluruhan perekonomian dan menemukan bahwa konten impor yang terkandung dalam ekspor Tiongkok sekitar 50\% pada tahun 2002 yang ternyata lebih dua kali lipat dibanding menghitungnya dengan vertical specialization (Koopman et al., 2012). Studi empiris lain terkait GVC menggunakan data Global Trade Analysis Project (GTAP) menemukan bahwa jika menggunakan perhitungan perdagangan nilai tambah, defisit neraca perdagangan antara
Amerika Serikat dengan Tiongkok turun $30-40 \%$ dibandingkan jika dihitung dengan data perdagangan tradisional (Johnson \& Noguera, 2012). Penelitian yang menjadi pondasi para peneliti untuk melakukan studi empiris GVC adalah metode dekomposisi gross exports menjadi empat sumber perhitungan nilai tambah yakni domestic value added absorbed abroad, domestic value added first exported then returned home, foreign value added dan pure double counted terms. Dari ke empat sumber tersebut dipecah lagi berdasarkan mekanisme dagangnya (Koopman et al., 2014)

Berdasarkan metode KWW tersebut, badan internasional dan universitas mengembangkan database input - output antar negara yang dibangun dari data nasional seperti World Input - Output Database (WIOD) oleh Universitas Groningen lalu Trade in Value Added database (TiVA) oleh Organisastion for Economic Cooperation and Development (OECD) serta Eora global supply chain database oleh Universitas Sydney. Saat ini tiga sumber data tersebut banyak digunakan oleh peneliti untuk melakukan penelitian empiris terkait GVC.

\section{Partisipasi dalam GVC}

Hampir seluruh negara di dunia berpartisipasi dalam GVC namun tingkat keterlibatannya berbeda-beda. Partisipasi suatu negara dalam GVC merupakan gabungan dari backward dan forward participation. Indikator persentase backward dan forward participation dapat dihitung menggunakan pendekatan perhitungan yang dilakukan oleh Lembaga internasional Organisastion for Economic Cooperation and Development (OECD).

- $\quad$ Backward Participation (\%): adalah nilai tambah dari asing yang terkandung dalam ekspor dihitung dalam persentase dari total ekspor suatu negara, OECD menyebutnya dengan indikator DEXFVAPSH. Indikator ini dibentuk dengan menghitung secara total rasio kandungan nilai tambah dalam barang impor yang diekspor kembali.

Forward Participation (\%): adalah nilai tambah dari ekspor domestik yang terkandung pada ekspor negara asing yang dihitung dalam persentase dari total ekspor dari negara sumber ekspor, OECD menyebutnya dengan indikator 
FEXDVAPSH. Indikator ini dibentuk dengan menghitung nilai tambah total dari ekspor yang berasal dari negara sumber ekspor dan terkandung pada negara asing pengekspor dibagi dengan nilai total ekspor negara sumber ekspor.

Studi empiris mengenai partisipasi GVC semakin banyak dilakukan seiring dengan bertambahnya ketersediaan data international input-output yang lebih mudah untuk digunakan namun tidak ada suatu model khusus yang digunakan. Salah satu studi empiris pertama terkait partisipasi GVC dilakukan oleh Kowalski (Kowalski et al., 2015) yang membagi jadi faktor yakni non kebijakan atau faktor struktural yakni ukuran pasar, level pembangunan industri dan struktur industri, jarak serta faktor yang terkait dengan kebijakan antara lain tarif serta perjanjian dagang, foreign direct investment serta kinerja logistik, kualitas infrastruktur, fasilitasi perdagangan, perlindungan kekayaan intelektual serta kualitas dari institusi pada negara berkembang. Menggunakan regresi panel data, semakin tinggi pendapatan suatu negara berpengaruh terhadap partisipasi GVC secara keseluruhan, liberalisasi tarif, serta logistik dan perlindungan kekayaan intelektual berpengaruh pada partisipasi GVC secara signifikan. Studi menemukan bahwa arus masuk FDI berpengaruh pada backward participation namun tidak signifikan terhadap forward participation.

Penelitian di kawasan Afrika barat dengan menggunakan model gravitasi dengan panel fixed effects menunjukkan hasil yang berbeda bahwa peningkatan PDB mendorong forward participation namun tidak berpengaruh terhadap backward participation di kawasan tersebut. Peningkatan tarif memberikan pengaruh positif bagi backward participation di dalam kawasan karena negara dalam kawasan dapat menyuplai barang antar negara di Kawasan (Tinta, 2017). Sedangkan pada kawasan yang berbeda yakni kawasan Uni Eropa, menggunakan panel data dinamis dengan metode GMM pada keseluruhan UE, UE-15 dan UE new member states (NMS) dan melihat pengaruhnya pada partisipasi GVC. Studi menemukan bahwa PDB berpengaruh terhadap partisipasi GVC secara keseluruhan namun FDI memiliki pengaruh yang positif dan signifikan pada UE NMS namun negatif dan signifikan pada UE 15, hal ini disebabkan UE NMS membutuhkan lebih banyak investasi asing terutama di bidang riset untuk meningkatkan volume produksi dan kualitas produk (Kersan-Škabić, 2019).

GVC berkontribusi secara positif terhadap FDI bilateral (Martínez-Galán \& Fontoura, 2019) serta studi lain dengan menggunakan estimasi IV antar negara di 100 negara menemukan bahwa sumber daya yang dimiliki suatu negara, jarak geografis, stabilitas politik, kebijakan perdagangan, FDI dan kapasitas industri (Fernandes et al., 2020). Studi yang dilakukan oleh Banerjee menggunakan panel data fixed effects didapatkan hasil bahwa ukuran suatu negara dan aliran FDI merupakan determinan utama dari partisipasi dalam GVC dikarenakan dapat mendorong industri untuk meningkatkan kemampuannya sehingga mampu mengimpor produk antara untuk diolah dan diekspor kembali. Ekspor produk manufaktur baik teknologi tinggi dan teknologi rendah mendorong backward participation namun produk manufaktur teknologi tinggi memberi dampak yang lebih kuat terhadap backward participation. Studi juga menemukan hal baru bahwa negara yang memiliki sumber daya dan institusi yang berkualitas tidak memiliki pengaruh signifikan terhadap partisipasi GVC(Banerjee \& Zeman, 2020).

Literatur terkait partisipasi GVC tersebut menemukan bahwa faktor yang mempengaruhi partisipasi GVC bervariatif antar negara bahkan antara negara dalam suatu kawasan seperti uni eropa terdapat perbedaan faktor dikarenakan tingkat perkembangan negara, kondisi industri dan perekonomian suatu negara sangat bervariatif. Faktor yang berpengaruh bagi negara berpendapatan rendah belum tentu berpengaruh bagi negara berpendapatan tinggi baik dari sisi forward maupun backward participation. Berdasarkan tinjauan literatur tersebut, penulis tidak menemukan studi yang menganalisis secara empiris faktor-faktor yang mempengaruhi partisipasi GVC di negara ASEAN 6. 


\section{METODE PENELITIAN}

\section{Model}

Studi literatur menunjukkan bahwa negara berpartisipasi dalam GVC melalui dua tipe partisipasi yakni backward participation atau partisipasi dengan keterkaitan ke belakang serta forward participation atau partisipasi dengan keterkaitan ke depan. Negara yang memiliki keterkaitan ke depan yang tinggi umumnya memiliki keterkaitan ke belakang yang lebih rendah. Forward participation umumnya melibatkan barang - barang primer yang digunakan sebagai bahan baku industri di negara tujuan ekspor (upstream) sedangkan backward participation umumnya melibatkan produk-produk yang diolah dari barang antara ke barang jadi (downstream) (ADB, 2019; Kowalski et al., 2015), dengan demikian perlu dibedakan proses identifikasi faktor pendorong dan rekomendasi kebijakan terhadap kedua tipe partisipasi GVC tersebut.

Model yang digunakan untuk penelitian ini menggunakan dasar model yang digunakan oleh (Kowalski et al., 2015)

FORWARD $_{i t}=f\left(N P O L_{i t}^{1}, \ldots, N P O L_{i t}^{N}, P O L_{i t}^{1}, \ldots P O L_{i t}^{M}, \varepsilon_{i t}\right)$

$B A C K W A R D_{i t}=f\left(N P O L_{i t}^{1}, \ldots, N P O L_{i t}^{N}, P O L_{i t}^{1}, \ldots P O L_{i t}^{M}, \varepsilon_{i t}\right)$

Kowalski melakukan analisis partisipasi GVC dengan model panel statis dan membagi fokus analisis partisipasi GVC baik forward dan backward lalu melihat hubungannya dengan indikator kebijakan dan indikator non kebijakan. Penelitian ini menggunakan indikator yang memiliki keterkaitan dengan nilai tahun sebelumnya seperti persentase GVC, Ekspor, FDI, PDB.. Model statis memiliki keterbatasan karena belum mempertimbangkan keterkaitan dengan nilai masa lalu, maka penelitan terkait partisipasi GVC oleh (Kersan-škabić, 2019) menggunakan model dinamis dengan model sebagai berikut:

$\left.Y_{i t}=\delta Y_{i t-1}+L_{i t}+\varepsilon_{i t}\right)$

$Y_{i t}$ : Partisipasi GVC

$Y_{i t-1}$ : Partisipasi GVC dengan lag

$L_{i t}:$ Variabel independent

$\varepsilon_{i t}:$ error
Penelitian ini berfokus pada hubungan partisipasi Forward GVC dengan ekspor komoditi primer karet dan CPO serta partisipasi Backward GVC dengan ekspor manufaktur otomotif dan manufaktur yang akan diteliti menggunakan model Kowalski dimodifikasi dengan model panel dinamis Skabic sebagai berikut:

$F G V C_{n t}=\beta_{0}+\beta_{1} F G V C_{n t-1}+$

$\beta_{2}$ Ekspor Komoditi Primer Karet $_{n t}+$

$\left(\beta_{1} N P O L_{n t}^{1}, \ldots \beta_{N} N P O L_{n t}^{N}, \beta_{1} P O L_{n t}^{1}, \ldots \beta_{N} P O L_{n t}^{M}, \varepsilon_{n t}\right.$ (1)

$F G V C_{n t}=\beta_{0}+\beta_{1} F G V C_{n t-1}+$

$\beta_{2}$ Ekspor Komoditi Primer CPO ${ }_{n t}+$

$\left(\beta_{1} N P O L_{n t}^{1}, \ldots \beta_{N} N P O L_{n t}^{N}, \beta_{1} P O L_{n t}^{1}, \ldots \beta_{N} P O L_{n t}^{M}, \varepsilon_{n t}\right.$ (2)

$B G V C_{n t}=\beta_{0}+\beta_{1} B G V C_{n t-1}+$

$\beta_{2}$ Ekspor Komoditi Manufaktur Otomotif $f_{n t}+$

$\left(\beta_{1} N P O L_{n t}^{1}, \ldots \beta_{N} N P O L_{n t}^{N}, \beta_{1} P O L_{n t}^{1}, \ldots \beta_{N} P O L_{n t}^{M}, \varepsilon_{n t}\right.$ (3)

$B G V C_{n t}=\beta_{0}+\beta_{1} B G V C_{n t-1}+$

$\beta_{2}$ Ekspor Komoditi Manufaktur Elektronik $k_{n t}+$ $\left(\beta_{1} N P O L_{n t}^{1}, \ldots \beta_{N} N P O L_{n t}^{N}, \beta_{1} P O L_{n t}^{1}, \ldots \beta_{N} P O L_{n t}^{M}, \varepsilon_{n t}\right.$ (4)

FGVC: forward participation pada negara $n$ dan tahun $t$.

BGVC: backward participation pada negara $n$ dan tahun t.

NPOL: faktor non kebijakan pada negara $n$ dan tahun $\dagger$ (NPOLint, ... , NPOLNnt

POL yaitu faktor terkait kebijakan pada negara n dan tahun $\dagger$ (POL 1nt, ... , POLNnt)

nilai ekspor: komoditi primer karet dan CPO serta manufaktur otomotif dan elektronik.

n: negara

t: tahun

$\varepsilon$ : error

Data yang digunakan adalah balanced panel dengan dimensi cross-sectional direpresentasikan oleh negara $(i=1 ;: .: ; N)$ serta dimensi longitudinal direpresentasikan dengan waktu secara serial ( $t=1 ;: .:$; periode T). (Hsiao, 2003).

Model panel dinamis dipilih berdasarkan asumsi bahwa variabel yang digunakan dipengaruhi oleh nilai tahun sebelumnya atau endogenitas sehingga perlu digunakan model dinamis. Sampel yang digunakan relatif sedikit sehingga tidak perlu menggunakan two step GMM dan cukup 1 step GMM karena menggunakan two step GMM pada sampel yang kecil memberikan hasil yang kurang akurat. 
Metode panel menggunakan GMM perlu dilakukan tes untuk melihat autokorelasi pada model dengan tes first order dan second order, tes ini perlu dilakukan guna memastikan bahwa model yang digunakan sudah mengatasi permasalahan tersebut (Arellano \& Bond, 1991). Pengolahan data statistik menggunakan Stata versi 16.

Beberapa kebaruan dalam penelitian ini dibandingkan dengan penelitian empiris GVC sebelumnya adalah menggunakan data partisipasi GVC dari TiVA versi 2018 serta dilakukan perbedaan antara backward dan forward participation, data ekspor komoditi primer dan manufaktur sebagai variabel serta model yang digunakan adalah dinamis, regresi dilakukan untuk masing-masing produk karena variabel kontrol yang digunakan berbeda pada tiap model.

\section{Data}

Data utama yang digunakan dalam penelitian ini menggunakan data panel dari 6 negara di ASEAN antara lain Indonesia, Malaysia, Singapura, Thailand, Vietnam dan Filipina. Data yang digunakan untuk penelitian ini adalah kombinasi data GVC Participation yang tersedia dari database Organisation for Economic Co-operation and Development Trade in Value Added (OECD TiVA) versi terbaru yang diluncurkan pada tahun 2019 yakni TiVA data versi 2018. Data tersebut dikombinasikan dengan data indikator ekonomi makro dari World Bank yakni World Development Indicators, Global Competitiveness Index, Ease of Doing Business, UNCTAD statistics serta data ekspor yang diambil dari data UN Comtrade menggunakan Trademap.

Data terkait partisipasi GVC berupa backward participation dan forward participation diunduh dari dari OECD TiVA database versi 2018. TiVA sendiri adalah database indikator terkait perdagangan nilai tambah yang dibangun berdasarkan tabel OECD InterCountry Input Output (IClO) mencakup data periode 2005-2015 untuk 64 negara yang terdiri dari semua anggota OECD, Uni Eropa, anggota G20 serta negara-negara besar di kawasan Asia.
Studi terkait partisipasi GVC menggunakan data TiVA telah banyak dilakukan (KersanŠkabić, 2019; Kowalski et al., 2015; Taglioni \& Winkler, 2016; Tinta, 2017). Beberapa sumber data lain terkait dengan GVC adalah UNCTAD EORA dan WIOD (world input output database). Hal yang membedakan adalah cakupan negara serta kemudahan dalam akses dan pengolahan data, OECD TiVA database lebih unggul karena mudah diakses dan sistem database yang lebih sederhana namun di satu sisi periode data yang tersedia baru tahun 2005 - 2015 untuk OECD TiVA versi terbaru yakni 2018.

Terdapat 2 faktor utama yang mempengaruhi partisipasi GVC suatu negara, yang pertama adalah non kebijakan atau faktor struktural serta faktor kebijakan terkait perdagangan, investasi dan kebijakan lain (Kowalski et al., 2015). Penelitian ini menggunakan beberapa indikator yang mewakili faktor utama tersebut. Faktor non kebijakan mencakup sumber daya menggunakan indikator natural resource rent, kemampuan industri dengan indikator medium dan high tech export serta ukuran ekonomi melalui GDP. Faktor kebijakan perdagangan melalui data FDI serta weighted tariff. Faktor kebijakan lainnya seperti kualitas institusi menggunakan indeks stabilitas politik, kualitas institusi keuangan menggunakan domestic credit to private sector, tingkat inovasi yang ditunjukkan dengan intellectual property protection, infrastruktur menggunakan indeks kualitas infrastruktur.

Faktor kualitas sumber daya manusia merupakan faktor yang tentunya akan berpengaruh pada partisipasi GVC karena industri membutuhkan sumber daya manusia yang berkualitas. Untuk menjelaskan sumber daya manusia tersebut penelitian ini menggunakan variabel kualitas institusi serta perlindungan atas kekayaan intelektual karena faktor sumber daya manusia pada bidang tersebut yang diindikasikan akan berpengaruh terhadap perdagangan dengan skema GVC.

\section{Variabel}

Sumber data dan definisi variabel yang digunakan mencakup data periode 2005-2015 dengan detail sebagaimana terlampir: 
Backward participation: merupakan persentase nilai tambah dari produk impor barang antara yang terkandung dalam nilai total ekspor. Pada data TiVA, ini dicerminkan pada indikator "DEXFVApSH": Backward participation in GVCs, percentage dari OECD TiVA edisi 2018. (OECD, 2019)

Forward participation: adalah persentase dari total ekspor yang merupakan nilai tambah domestik yang terkandung dalam ekspor negara pengekspor, indikator ini dicerminkan pada indikator "FEXDVApSH": Forward participation in GVCs, percentage dari OECD TiVA edisi 2018. (OECD, 2019)

Data Ekspor komoditi primer dan manufaktur: nilai ekspor komoditi primer menggunakan data ekspor produk CPO (HS 1511) dan karet (HS 4001) sedangkan ekspor manufaktur menggunakan data ekspor produk elektronik (HS 85) dan ekspor otomotif (HS 87) dalam satuan ribu USD, data didapatkan dari trademap.

GDP konstan 2010 USD: merupakan total nilai barang dan jasa yang dihasilkan oleh suatu negara menggunakan harga konstan tahun 2010 kurs USD. Data didapatkan dari World Development Indicators (WDI) world bank dan OECD data.

Besaran tarif, applied, rata-rata tertimbang, semua produk: merupakan persentase besaran applied tariff yang dikenakan untuk produk impor. Rata-rata tertimbang diukur berdasarkan pangsa impor dari tiap mitra dagang.

Aliran masuk FDI: aliran masuk modal asing dalam juta USD. Sumber data dari UNCTAD statistik.

Stablilitas politik dan tidak adanya
kekerasan/terorisme: sebagai estimasi
kemampuan Pemerintah negara memastikan
stabilitas dan keamanan negara. Data dari
World Governance Indicator (WGI) world bank.

Pendapatan dari sumber daya alam atau natural resources rent: total pendapatan yang didapatkan dari kegiatan ekstraksi sumber daya alam baik minyak, tambang, gas, mineral dan hutan dalam persentase dibandingkan GDP. Sumber data dari WDI world bank.
Kredit domestik untuk swasta: fasilitas pembiayaan melalui institusi finansial melalui pinjaman yang diterima oleh sektor swasta berdasarkan persentase dari GDP. Data bersumber dari Global Financial Development (GFC) world bank

Ekspor manufaktur teknologi menengah dan tinggi: total ekspor teknologi menengah dan tinggi dihitung dari persentase total ekspor manufaktur. Data didapatkan dari WDI world bank.

Perlindungan hak kekayaan intelektual: menggunakan skala 1 yang terendah hingga 7 terbaik - Dataset Global Competitiveness Index

Kualitas infrastruktur dan pelabuhan: menggunakan skala 1 yang terendah hingga 7 terbaik - Dataset Global Competitiveness Indeks

\section{HASIL DAN PEMBAHASAN Pangsa Produk}

Tabel 1 dan 2 menunjukkan persentase pangsa ekspor produk CPO dan Karet dibandingkan dengan total ekspor produk primer dan pangsa ekspor otomotif dan elektronik dibandingkan total ekspor produk manufaktur dari tiap negara dan total keseluruhan ASEAN 6.

Tabel 1. Pangsa Ekspor Produk Primer

\begin{tabular}{|c|c|c|c|c|c|c|c|c|c|c|c|c|c|c|}
\hline \multicolumn{15}{|c|}{ Pangsa produl Primer (\%or) } \\
\hline & \multicolumn{2}{|c|}{ Indonsia } & \multicolumn{2}{|c|}{ Malaysia } & \multicolumn{2}{|c|}{ Singapura } & \multicolumn{2}{|c|}{ Thailand } & \multicolumn{2}{|c|}{ Vetanam } & \multicolumn{2}{|c|}{ Filipina } & \multicolumn{2}{|c|}{ ASEAN6 } \\
\hline Talun & CPO & Karet & CPO & Karet & CPO & Karet & CPO & Karet & CPO & Karet & CPO & Karet & CPO & Karet \\
\hline 2005 & 8,34 & 5,74 & 12,88 & 4,5 & 0.29 & 0,80 & 0,18 & 14,92 & 0,01 & & 0,00 & 0,82 & 5,08 & 5,49 \\
\hline 2006 & 8,64 & 7,75 & 13,19 & 5,69 & 0,24 & 0,83 & 0,28 & 17,29 & 0,01 & 5,89 & 0,00 & 0,74 & 5,11 & 6,79 \\
\hline 2007 & 12,08 & 7,48 & 17, & 4,46 & 0,28 & 0,58 & 0,53 & 15,19 & 0,03 & 3,99 & 0,00 & 0,34 & 6,99 & 6,07 \\
\hline 2008 & 14,85 & 7,27 & 19,02 & 3,63 & 0,33 & 0,77 & 0,70 & 13,45 & 0,05 & 5,52 & 0,00 & 0,02 & 8,13 & 5,45 \\
\hline 2009 & 15,03 & 4,70 & 20,09 & 2,75 & 0,36 & 0,33 & 0,20 & 9,77 & , , II & 4,4 & 0,00 & 0,45 & 8,19 & 4,17 \\
\hline 2010 & 13,71 & 7,46 & 19,62 & 4,53 & 0,27 & 0,53 & 0,21 & 14,32 & 0,07 & 8,07 & 0,04 & 0,74 & 8,08 & 6,36 \\
\hline 2011 & 12,95 & 8,83 & 20,9 & 5,22 & 0,20 & 0,48 & 0,56 & 18,48 & 0,15 & 8,6 & 0,02 & 0,80 & 8,08 & 7,51 \\
\hline 2012 & 14,66 & 6,55 & 18,4 & 3,01 & 0,11 & 0,31 & 0,4 & 12,68 & 0,18 & 6,86 & 0,33 & 0,65 & 7,97 & 5,24 \\
\hline 2013 & 14,05 & 6,13 & 14,12 & 2,56 & 0,09 & 0,18 & 0,68 & 12,93 & 0.14 & 6,83 & 0,41 & 0,01 & 6.96 & 4,84 \\
\hline 2014 & 17,02 & 4,62 & 13, & 1,60 & 0,09 & 0,15 & 0,33 & 9,94 & 0,14 & 4,50 & 0,28 & 0,00 & 7,47 & 3,52 \\
\hline 2015 & 18,78 & 4,52 & 14,66 & 1,60 & 0,09 & 0,18 & 0,09 & 9,25 & 0,16 & 3,38 & 0,14 & 0,01 & 8,27 & 3,61 \\
\hline
\end{tabular}

Sumber: UN Comtrade, Diolah (2020) 
Tabel 2. Pangsa Ekspor Produk Manufaktur

\begin{tabular}{|c|c|c|c|c|c|c|c|c|c|c|c|c|c|c|}
\hline \multicolumn{15}{|c|}{ Pangsa Produk Manufafaktur (\%) } \\
\hline & \multicolumn{2}{|c|}{ Indonesia } & \multicolumn{2}{|c|}{ Malaysia } & \multicolumn{2}{|c|}{ Simpopra } & \multicolumn{2}{|c|}{ Thailand } & \multicolumn{2}{|c|}{ Vietram } & \multicolumn{2}{|c|}{ Filipina } & \multicolumn{2}{|c|}{ ASEAN6 } \\
\hline Tahun & Otomonif & Eleltroik & Otomonif & Eleltronik & Otomonif & $f$ Eleltroonik & Otomonif & Eleltronik & Otomifif & Eleltroonik & Otomonif & Eleltroik & Otomaif & Eleltroik \\
\hline 2005 & 3,22 & 18,15 & 0,77 & 4,47 & 1,40 & 17,0 & 9,58 & 24,23 & 2,25 & 9,46 & 4,40 & 35,01 & 3,13 & 27,99 \\
\hline 2006 & 3,72 & 16,27 & 0,79 & 41,30 & 1,27 & 18,11 & 10,21 & 23,41 & 2.21 & 10,07 & 3,81 & 54,17 & 3,19 & 26,37 \\
\hline 2007 & 4,35 & \begin{tabular}{|l|l|}
15,47 \\
\end{tabular} & 0,91 & 40,30 & 1,39 & 43,92 & 11,02 & 22,18 & 2,19 & 1228 & 4,23 & 51,84 & 3,61 & 35,89 \\
\hline 2008 & 5.29 & 15,50 & 1,01 & 2391 & 1,60 & 4,12 & 13,11 & 2026 & 1,84 & 10,67 & 5,48 & 51,4 & 4.29 & \begin{tabular}{|l|l}
30,47 \\
\end{tabular} \\
\hline 2009 & 3,86 & 17,23 & 1,02 & 40,70 & 1,60 & 40,24 & 11,08 & 20,67 & 1,57 & 12,47 & 4,80 & 47,54 & 3,73 & 33,23 \\
\hline 2010 & 4,88 & 17,45 & 1,11 & 41,17 & 1,49 & 42,57 & 13,27 & 20,67 & 1,53 & 15,29 & 4,24 & 32,36 & 4,22 & 33,39 \\
\hline 2011 & 4,75 & 15,89 & 1,09 & 42,70 & 1,59 & 384,48 & 11,54 & 19,36 & 1,50 & 20,65 & 5,87 & 31,24 & 3,98 & \begin{tabular}{|l|}
31,61 \\
\end{tabular} \\
\hline 2012 & 6,95 & 15,41 & 1,27 & 4,53 & 1,75 & 37,52 & 15,14 & 18,06 & 1,69 & 28,71 & 4,53 & 48,12 & 4.2 & 32.16 \\
\hline 2013 & 6,55 & 14,97 & 1,33 & 43,03 & 1,38 & 39,08 & 15,89 & 17,93 & 1,65 & 33,26 & 3,60 & 48,66 & 4,82 & 333,39 \\
\hline 2014 & 7,11 & 13,29 & 1,33 & 4,74 & 1,34 & 39,43 & 15,59 & 18,42 & 1,69 & 32,29 & 3,42 & 47,58 & 4,4 & 33,59 \\
\hline 2015 & 7,94 & 12,54 & 1,32 & 4,08 & 1,33 & 4,51 & 16,92 & 18,68 & 1,46 & 36,36 & 290 & 5275 & 4,96 & \begin{tabular}{|l|l} 
\\
35,05
\end{tabular} \\
\hline
\end{tabular}

Secara keseluruhan pada wilayah ASEAN 6 periode 2005-2015, pangsa ekspor komoditi primer komoditi CPO relatif stabil dan mencapai angka tertinggi yaitu $8,27 \%$ di tahun 2015 sedangkan ekspor karet berfluktuasi dengan kecenderungan turun. Negara yang mayoritas ekspor komoditi primernya CPO adalah Indonesia sedangkan yang mayoritas ekspor komoditi primernya karet adalah Thailand. Sedangkan pada komoditi manufaktur ekspor otomotif dan elektronik mencapai pangsa tertinggi pada tahun 2015 dengan ekspor otomotif memiliki pangsa $4,96 \%$ sedangkan elektronik mencapai $35,05 \%$. Thailand merupakan negara dengan mayoritas ekspor otomotif yang besar dibandingkan dengan total ekspor manufaktur, sedangkan Malaysia, Singapura, Vietnam dan Filipina ekspor elektronik memiliki pangsa lebih dari $30 \%$ total ekspor manufakturnya.

\section{Hasil Regresi}

Berikut adalah hasil analisis regresi terhadap faktor yang berhubungan dengan forward participation menggunakan variabel ekspor karet dan CPO sebagai variabel interest terlampir pada tabel 3 dan tabel 4 .

\section{Tabel 3. Hasil regresi dengan ekspor karet $($ Log forward GVC participation $=$ Dependen variabel)}

\begin{tabular}{|c|c|c|c|c|c|c|}
\hline & Model 1 & Model 2 & Model 3 & Model 4 & Model 5 & Model 6 \\
\hline L.lFGVCpart & $\begin{array}{c}0.568^{* * * *} \\
(0.124)\end{array}$ & $\begin{array}{c}0.545^{* * * * *} \\
(0.105)\end{array}$ & $\begin{array}{c}0.581^{* * * *} \\
(0.114)\end{array}$ & $\begin{array}{c}0.508^{* * * *} \\
(0.128)\end{array}$ & $\begin{array}{c}0.603 * * * * \\
(0.112)\end{array}$ & $\begin{array}{l}0.508^{* * * * *} \\
(0.108)\end{array}$ \\
\hline INRBexp & $\begin{array}{c}0.0321^{*} \\
(0.0165)\end{array}$ & $\begin{array}{l}0.0385^{* * *} \\
(0.0159)\end{array}$ & $\begin{array}{l}0.0347^{* * *} \\
(0.0161)\end{array}$ & $\begin{array}{l}0.0355^{* * *} \\
(0.0177)\end{array}$ & $\begin{array}{c}0.0280^{*} \\
(0.0169)\end{array}$ & $\begin{array}{c}0.0304 * \\
(0.0183)\end{array}$ \\
\hline L.1NRBexp & $\begin{array}{c}-0.0432^{* * *} \\
(0.0177)\end{array}$ & $\begin{array}{c}-0.0429 * * * * \\
(0.0161)\end{array}$ & $\begin{array}{c}-0.0496 * * * \\
(0.0168)\end{array}$ & $\begin{array}{c}-0.0492^{* * * *} \\
(0.0178)\end{array}$ & $\begin{array}{c}-0.0476 \text { **** } \\
(0.0180)\end{array}$ & $\begin{array}{l}-0.0417^{* * *} \\
(0.0181)\end{array}$ \\
\hline IFDIinUSD & $\begin{array}{c}0.0358 \text { **** } \\
(0.0117)\end{array}$ & $\begin{array}{c}0.0331 \text { **** } \\
(0.0117)\end{array}$ & 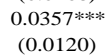 & & $\begin{array}{c}0.0297 \text { **** } \\
(0.0107)\end{array}$ & \\
\hline lGDPcons & $\begin{array}{c}-0.0927 \text { ** } \\
(0.0461)\end{array}$ & $\begin{array}{l}-0.0115 \\
(0.0863)\end{array}$ & $\begin{array}{c}-0.0989 * * \\
(0.0466)\end{array}$ & & & $\begin{array}{c}0.0278 \\
(0.0535)\end{array}$ \\
\hline TECHex & $\begin{array}{c}-0.000722 \\
(0.00123)\end{array}$ & & & $\begin{array}{l}-0.000598 \\
(0.00136)\end{array}$ & & \\
\hline IPolstab & $\begin{array}{c}0.00271 \\
(0.00728)\end{array}$ & & & & $\begin{array}{c}0.00118 \\
(0.00749)\end{array}$ & $\begin{array}{c}0.00546 \\
(0.00767)\end{array}$ \\
\hline lQualInfra & & $\begin{array}{c}-0.104 \\
(0.0865)\end{array}$ & & & & $\begin{array}{c}0.0373 \\
(0.0805)\end{array}$ \\
\hline DOMcred & & $\begin{array}{l}-0.000784 \\
(0.000820)\end{array}$ & & $\begin{array}{c}0.000345 \\
(0.000585)\end{array}$ & $\begin{array}{c}-0.000161 \\
(0.000540)\end{array}$ & \\
\hline ITrfwght & & & $\begin{array}{l}0.00194 \\
(0.0141)\end{array}$ & $\begin{array}{l}-0.0122 \\
(0.0148)\end{array}$ & $\begin{array}{l}-0.0149 \\
(0.0155)\end{array}$ & \\
\hline IIPRpro & & & $\begin{array}{c}0.0211 \\
(0.0622)\end{array}$ & $\begin{array}{c}0.0994 \\
(0.0647)\end{array}$ & & \\
\hline Natres & & & & $\begin{array}{l}0.0107 * * \\
(0.00431)\end{array}$ & $\begin{array}{c}0.00957 * * \\
(0.00376)\end{array}$ & $\begin{array}{c}0.00835^{*} \\
(0.00457)\end{array}$ \\
\hline Observations & 54 & 54 & 54 & 54 & 54 & 54 \\
\hline AR(1) p-value & 0.0026 & 0.0032 & 0.0027 & 0.0005 & 0.0016 & 0.0019 \\
\hline $\mathrm{AR}(2) \mathrm{p}$-value & 0.8008 & 0.6899 & 0.7209 & 0.4723 & 0.3498 & 0.5629 \\
\hline Sargan test & 0.4581 & 0.4496 & 0.3992 & 0.5119 & 0.7798 & 0.3543 \\
\hline
\end{tabular}

Berdasarkan tabel 3 diatas, faktor yang signifikan berhubungan dengan forward participation adalah ekspor karet baik tahun ini maupun pada tahun sebelumnya, lag dari variabel dependen, aliran masuk FDI, GDP serta pendapatan dari sumber daya. Lag dependen variabel, ekspor karet tahun ini, arus masuk FDI serta pendapatan dari sumber daya alam memiliki hubungan positif sedangkan ekspor karet tahun sebelumnya dan GDP memiliki hubungan negatif.

Lebih lanjut pada tabel 4, faktor yang positif dan signifikan berhubungan dengan forward participation adalah lag dependen variabel, FDI, pendapatan dari sumber daya alam dan kualitas infrastruktur. Sedangkan GDP dan ekspor CPO negatif dan signifikan. Ekspor CPO ini menggunakan variabel ekspor dengan lag 2 tahun karena diasumsikan ekspor CPO berhubungan positif dengan forward participation namun dengan menggunakan variabel ekspor lag 2 tahun tetap secara robust menunjukkan hubungan negatif antara ekspor CPO dengan forward participation. 


\begin{tabular}{|c|c|c|c|c|c|c|}
\hline \multicolumn{7}{|c|}{$\begin{array}{c}\text { Tabel 4. Hasil regresi dengan ekspor CPO } \\
\text { (Log forward GVC participation = Dependen } \\
\text { variabel) }\end{array}$} \\
\hline & Model 1 & Model 2 & Model 3 & Model 4 & Model 5 & Model 6 \\
\hline L.IFGVCpart & $\begin{array}{c}0.451^{* * * *} \\
(0.128)\end{array}$ & $\begin{array}{c}0.436 * * * \\
(0.130)\end{array}$ & $\begin{array}{c}0.432 * * * * \\
(0.147)\end{array}$ & $\begin{array}{c}0.503 * * * * \\
(0.124)\end{array}$ & $\begin{array}{c}0.468 * * * \\
(0.115)\end{array}$ & $\begin{array}{l}0.487^{* * * *} \\
(0.113)\end{array}$ \\
\hline 1CPOexp & $\begin{array}{c}-0.0339 * * * * \\
(0.0120)\end{array}$ & $\begin{array}{c}-0.0371^{* * * * *} \\
(0.0122)\end{array}$ & $\begin{array}{c}-0.0192 \\
(0.0140)\end{array}$ & $\begin{array}{c}-0.00943 \\
(0.00932)\end{array}$ & $\begin{array}{c}-0.00624 \\
(0.00947)\end{array}$ & $\begin{array}{l}-0.00326 \\
(0.00973)\end{array}$ \\
\hline L.1CPOexp & $\begin{array}{l}0.00893 \\
(0.0103)\end{array}$ & $\begin{array}{l}0.00937 \\
(0.0103)\end{array}$ & $\begin{array}{l}0.00532 \\
(0.0121)\end{array}$ & $\begin{array}{c}-0.00554 \\
(0.00976)\end{array}$ & $\begin{array}{r}-0.00947 \\
(0.00969)\end{array}$ & $\begin{array}{c}-0.00519 \\
(0.00997)\end{array}$ \\
\hline L2.1CPOexp & $\begin{array}{l}-0.00774 \\
(0.00984)\end{array}$ & $\begin{array}{l}-0.00393 \\
(0.00944)\end{array}$ & $\begin{array}{l}-0.00279 \\
(0.0108)\end{array}$ & & & \\
\hline 1GDPcons & $\begin{array}{c}0.0782 \\
(0.0656)\end{array}$ & & & $\begin{array}{l}-0.0387 \\
(0.101)\end{array}$ & $\begin{array}{l}-0.0369 \\
(0.0951)\end{array}$ & $\begin{array}{l}-0.135^{* * *} \\
(0.0607)\end{array}$ \\
\hline Natres & $\begin{array}{l}0.0184 * * * * \\
(0.00507)\end{array}$ & $\begin{array}{l}0.0173 \text { ****** } \\
(0.00477)\end{array}$ & $\begin{array}{l}0.0119^{* * *} \\
(0.00513)\end{array}$ & & & \\
\hline 1QualInfra & $\begin{array}{l}0.261 * * * \\
(0.0961)\end{array}$ & $\begin{array}{l}0.248^{* * * *} \\
(0.0939)\end{array}$ & $\begin{array}{c}0.165 \\
(0.105)\end{array}$ & & & \\
\hline ITrfwght & & $\begin{array}{c}-0.0151 \\
(0.0150)\end{array}$ & & & & $\begin{array}{c}0.0111 \\
(0.0134)\end{array}$ \\
\hline 1Polstab & & & $\begin{array}{c}0.00529 \\
(0.00835)\end{array}$ & & $\begin{array}{c}0.00794 \\
(0.00770)\end{array}$ & $\begin{array}{c}0.00723 \\
(0.00797)\end{array}$ \\
\hline IIPRpro & & & $\begin{array}{c}0.0379 \\
(0.0881)\end{array}$ & $\begin{array}{l}-0.0310 \\
(0.0736)\end{array}$ & & \\
\hline TECHex & & & $\begin{array}{c}-0.00203 \\
(0.00168)\end{array}$ & & & \\
\hline IFDIinUSD & & & & $\begin{array}{c}0.0440^{* * * *} \\
(0.0128)\end{array}$ & $\begin{array}{c}0.0413 * * * * \\
(0.0128)\end{array}$ & $\begin{array}{l}0.0464 * * * * \\
(0.0127)\end{array}$ \\
\hline DOMcred & & & & $\begin{array}{c}-0.00108 \\
(0.000907)\end{array}$ & $\begin{array}{c}-0.000917 \\
(0.000804)\end{array}$ & \\
\hline Observations & 43 & 43 & 43 & 43 & 43 & 43 \\
\hline $\mathrm{AR}(1) \mathrm{p}$-value & 0.0197 & 0.0162 & 0.0252 & 0.0107 & 0.0151 & 0.0117 \\
\hline $\mathrm{AR}(2) \mathrm{p}$-value & 0.4416 & 0.5079 & 0.3984 & 0.7624 & 0.6854 & 0.6111 \\
\hline Sargan test & 0.2001 & 0.2398 & 0.1173 & 0.2142 & 0.1899 & 0.2841 \\
\hline Standrord error & s in parentl & & & & & \\
\hline Sumber: ST & TA, D & h 12 & & & & \\
\hline
\end{tabular}

Tabel berikutnya yakni 5 dan 6 akan memaparkan hasil analisis terhadap faktor yang berhubungan dengan backward participation.

Tabel 5. Hasil regresi dengan ekspor otomotif (Log backward GVC participation $=$ Dependen variabel)

\begin{tabular}{|c|c|c|c|c|c|c|}
\hline & Model 1 & Model 2 & Model 3 & Model 4 & Model 5 & Model 6 \\
\hline \multirow[t]{2}{*}{ L.lBGVCpart } & 0.193 & 0.161 & $0.309^{* * * *}$ & $0.457 * * *$ & $0.282^{* * *}$ & $0.232 *$ \\
\hline & $(0.130)$ & $(0.133)$ & $(0.117)$ & $(0.149)$ & $(0.125)$ & $(0.121)$ \\
\hline \multirow[t]{2}{*}{ 1AUTOexp } & $0.164 * * *$ & $0.162 * * * *$ & $0.142 * * *$ & $0.143 * * *$ & $0.155^{* * * * *}$ & $0.170^{* * * *}$ \\
\hline & $(0.0491)$ & $(0.0483)$ & $(0.0473)$ & $(0.0519)$ & $(0.0521)$ & $(0.0472)$ \\
\hline \multirow[t]{2}{*}{ L.1AUTOexp } & -0.0825 & -0.0656 & $-0.125 * *$ & $-0.152^{* * * *}$ & $-0.146 * * * *$ & -0.0835 \\
\hline & $(0.0518)$ & $(0.0542)$ & $(0.0487)$ & $(0.0447)$ & $(0.0446)$ & $(0.0550)$ \\
\hline \multirow[t]{2}{*}{ IFDIinUSD } & 0.00563 & 0.00504 & & -0.0152 & -0.0265 & -0.00775 \\
\hline & $(0.0178)$ & $(0.0174)$ & & $(0.0167)$ & $(0.0172)$ & $(0.0179)$ \\
\hline \multirow[t]{2}{*}{ 1GDPcons } & $-0.413^{* * * *}$ & $-0.422^{* * * *}$ & & & & $-0.207^{*}$ \\
\hline & $(0.150)$ & $(0.147)$ & & & & $(0.115)$ \\
\hline \multirow[t]{2}{*}{ 1Trfwght } & 0.0216 & 0.0194 & & $0.0508 * *$ & & 0.0184 \\
\hline & (0.0190) & (0.0183) & & $(0.0224)$ & & $(0.0185)$ \\
\hline \multirow[t]{2}{*}{ IIPRpro } & 0.0993 & 0.128 & 0.0357 & & 0.0171 & 0.0822 \\
\hline & $(0.102)$ & $(0.106)$ & $(0.102)$ & & $(0.101)$ & $(0.0954)$ \\
\hline \multirow[t]{2}{*}{ TECHex } & 0.00285 & $0.00306^{*}$ & & 0.00269 & 0.00117 & \\
\hline & $(0.00181)$ & $(0.00175)$ & & $(0.00197)$ & $(0.00192)$ & \\
\hline \multirow[t]{2}{*}{ DOMcred } & 0.00191 & $0.00204 *$ & & & & \\
\hline & $(0.00116)$ & $(0.00115)$ & & & & \\
\hline \multirow[t]{2}{*}{ Natres } & & 0.00558 & 0.00277 & & & 0.00161 \\
\hline & & $(0.00623)$ & $(0.00683)$ & & & $(0.00623)$ \\
\hline \multirow[t]{2}{*}{ 1QualInfra } & & & -0.0998 & 0.0961 & -0.0354 & -0.0788 \\
\hline & & & $(0.118)$ & $(0.121)$ & $(0.120)$ & $(0.107)$ \\
\hline \multirow[t]{2}{*}{ lPolstab } & & & & & -0.000339 & \\
\hline & & & & & $(0.0112)$ & \\
\hline Observations & 54 & 54 & 54 & 54 & 54 & 54 \\
\hline $\operatorname{AR}(1) p$-value & 0.0160 & 0.0207 & 0.0129 & 0.0243 & 0.0396 & 0.0350 \\
\hline $\mathrm{AR}(2) \mathrm{p}$-value & 0.9810 & 0.7933 & 0.8974 & 0.8986 & 0.7851 & 0.9818 \\
\hline Sargan test & 0.2335 & 0.2042 & 0.5447 & 0.9412 & 0.7115 & 0.4996 \\
\hline
\end{tabular}

Berdasarkan tabel 5 diatas, faktor yang positif dan signifikan berhubungan dengan backward participation adalah adalah ekspor otomotif, lag dependen variabel tahun sebelumnya, pembiayaan dari domestik serta ekspor produk teknologi menengah dan tinggi serta tarif. Adapun yang memiliki hubungan negatif dan signifikan adalah ekspor produk otomotif tahun sebelumnya, GDP.

Lebih lanjut, berdasarkan tabel 6, faktor yang berhubungan dengan backward participation adalah lag dari dependen variabel, ekspor elektronik saat ini dan ekspor elektronik tahun sebelumnya, tarif, GDP, serta kualitas institusi keuangan dalam negeri.

Tabel 6. Hasil regresi dengan ekspor elektronik (Log backward GVC participation = Dependen variabel)

\begin{tabular}{|c|c|c|c|c|c|c|}
\hline & Model 1 & Model 2 & Model 3 & Model 4 & Model 5 & Model 6 \\
\hline$\overline{\mathrm{L} .1 \mathrm{BG}}$ & $\begin{array}{l}0.243^{*} \\
(0.140)\end{array}$ & $\begin{array}{c}0.168 \\
(0.136)\end{array}$ & $\begin{array}{c}0.363^{* * * *} \\
(0.121)\end{array}$ & $\begin{array}{c}0.339^{* * * *} \\
(0.121)\end{array}$ & $\begin{array}{l}0.316^{* * *} \\
(0.130)\end{array}$ & $\begin{array}{c}0.200 \\
(0.163)\end{array}$ \\
\hline 1ELECexp & $\begin{array}{l}0.155^{\text {***** }} \\
(0.0452)\end{array}$ & $\begin{array}{l}0.166^{* * * *} \\
(0.0499)\end{array}$ & $\begin{array}{l}0.152 * * * \\
(0.0474)\end{array}$ & $\begin{array}{l}0.152 * * * \\
(0.0466)\end{array}$ & $\begin{array}{l}0.149^{* * * *} \\
(0.0475)\end{array}$ & $\begin{array}{c}0.143 * * * \\
(0.0435)\end{array}$ \\
\hline L.1ELECexp & $\begin{array}{l}-0.0655 \\
(0.0616)\end{array}$ & $\begin{array}{l}-0.0675 \\
(0.0569)\end{array}$ & $\begin{array}{c}-0.131^{* * * * *} \\
(0.0494)\end{array}$ & $\begin{array}{c}-0.137 \text { **** } \\
(0.0481)\end{array}$ & $\begin{array}{l}-0.112 * * \\
(0.0556)\end{array}$ & $\begin{array}{l}-0.0854 * \\
(0.0499)\end{array}$ \\
\hline 1FDIinUSD & $\begin{array}{l}-0.00336 \\
(0.0179)\end{array}$ & $\begin{array}{l}0.00122 \\
(0.0181)\end{array}$ & $\begin{array}{l}-0.0193 \\
(0.0156)\end{array}$ & $\begin{array}{c}-0.0200 \\
(0.0153)\end{array}$ & $\begin{array}{c}-0.0188 \\
(0.0156)\end{array}$ & \\
\hline 1GDPcons & $\begin{array}{l}-0.211^{*} \\
(0.126)\end{array}$ & $\begin{array}{c}-0.403^{* *} \\
(0.160)\end{array}$ & & & & $\begin{array}{l}-0.209^{*} \\
(0.112)\end{array}$ \\
\hline 1Polstab & $\begin{array}{l}0.00314 \\
(0.0106)\end{array}$ & $\begin{array}{l}0.00251 \\
(0.0106)\end{array}$ & $\begin{array}{c}-0.000248 \\
(0.0107)\end{array}$ & & & \\
\hline Natres & $\begin{array}{c}0.00176 \\
(0.00606)\end{array}$ & $\begin{array}{c}0.00668 \\
(0.00621)\end{array}$ & $\begin{array}{c}0.00234 \\
(0.00624)\end{array}$ & $\begin{array}{c}0.00143 \\
(0.00620)\end{array}$ & $\begin{array}{c}0.00301 \\
(0.00622)\end{array}$ & \\
\hline 1Trfwght & $\begin{array}{c}0.0228 \\
(0.0177)\end{array}$ & & $\begin{array}{l}0.0325^{*} \\
(0.0188)\end{array}$ & $\begin{array}{c}0.0212 \\
(0.0209)\end{array}$ & $\begin{array}{c}0.0128 \\
(0.0199)\end{array}$ & \\
\hline 1QualInfra & $\begin{array}{l}-0.0327 \\
(0.101)\end{array}$ & $\begin{array}{l}-0.0301 \\
(0.116)\end{array}$ & & & & $\begin{array}{r}-0.00745 \\
(0.0981)\end{array}$ \\
\hline DOMcred & & $\begin{array}{l}0.00208^{*} \\
(0.00126)\end{array}$ & & & $\begin{array}{c}-0.000705 \\
(0.000914)\end{array}$ & \\
\hline TECHex & & $\begin{array}{c}0.00265 \\
(0.00183)\end{array}$ & & & & $\begin{array}{c}0.00121 \\
(0.00176)\end{array}$ \\
\hline IIPRpro & & $\begin{array}{c}0.122 \\
(0.110)\end{array}$ & & & & \\
\hline Observations & 54 & 54 & ד & 54 & 34 & 54 \\
\hline $\mathrm{AR}(1) \mathrm{p}$-value & 0.0240 & 0.0140 & 0.0345 & 0.0302 & 0.0291 & 0.0128 \\
\hline $\mathrm{AR}(2) \mathrm{p}$-value & 0.8795 & 0.7421 & 0.9544 & 0.9046 & 0.9710 & 0.9122 \\
\hline Sargan test & 0.4379 & 0.2671 & 0.6659 & 0.6730 & 0.6569 & 0.7226 \\
\hline
\end{tabular}

Standard errors in parentheses

$* \mathrm{p}<0.10, * * \mathrm{p}<0.05, * * * \mathrm{p}<0.01$

Sumber: STATA, Diolah (2020)

Total 6 model digunakan sebagai robustness check pada empat (4) komoditi tersebut dan telah melalui tes arellano bond yang memberikan hasil signifikan pada first order dan tidak signifikan pada second order hal ini menunjukkan bahwa semua model tersebut sudah robust dan telah mengatasi permasalahan autokorelasi. Sedangkan Sargan 
tes menunjukkan bahwa variabel yang digunakan tidak berkolerasi dengan eror dan dapat digunakan dalam model. Hasil regresi terhadap faktor-faktor yang berhubungan dengan partisipasi GVC memiliki beberapa perbedaan baik backward dan forward participation, hal ini sejalan dengan (Kowalski et al., 2015) dan (ADB, 2019) yang menyatakan bahwa backward dan forward participation umumnya memiliki karakteristik yang berbeda sehingga strategi untuk meningkatkan partisipasi GVC suatu negara harus disesuaikan apakah negara tersebut bertujuan untuk meningkatkan partisipasi ke depan atau ke belakang

\section{Analisis forward participation}

Pada kedua analisis forward participation, pengaruh ekspor karet tahun berjalan positif dan signifikan sedang ekspor tahun sebelumnya negatif dan signifikan. Sedangkan ekspor CPO di tahun berjalan negatif dan signifikan hal ini menunjukkan bahwa ekspor karet dan CPO berpengaruh terhadap forward participation.

Karet sudah positif dan signifikan sejalan dengan penelitian ADB yang menyatakan bahwa produk primer memiliki pengaruh positif terhadap forward participation dimana produk karet ASEAN 6 banyak di ekspor ke negara industri besar seperti Tiongkok, Amerika Serikat, Jepang, Korea, India dan sebagian diserap juga di ASEAN terutama oleh Malaysia. (Trademap, 2021). Sedangkan untuk produk CPO, berdasarkan data produksi beberapa negara produsen utama di ASEAN 6 yakni Indonesia, Malaysia dan Thailand dengan total estimasi produksi CPO pada tahun 2021 sebesar 67.300.000 Metrik Ton, sebesar lebih dari 36\% atau 24.601.000 Metrik ton diserap oleh domestik ASEAN 6 (United States Department of Agriculture, 2021), tingginya CPO yang diserap oleh domestik ini menyebabkan komoditi primer CPO di ASEAN 6 berpengaruh negatif dan signifikan pada forward participation.

Lag satu tahun dari dependen variabel untuk semua model menunjukkan hasil positif signifikan menunjukkan aspek dinamis dari variabel tersebut yang berarti tingkat forward participation tahun sebelumnya mempengaruhi partisipasi tahun sekarang.
Aliran FDI juga secara positif dan signifikan berhubungan dengan forward participation temuan ini sejalan dengan studi Martinez-Galan \& Fontoura (2019) dan Kowalski (2015). studi Kersan-Skabic (2019) yang juga menemukan bahwa negara anggota Uni Eropa new member state yang masih berkembang industrinya membutuhkan FDI untuk meningkatkan forward participation. Negara di kawasan ASEAN 6 dalam hal ini juga perlu terus meningkatkan kemudahan bagi investor untuk melakukan investasi. Salah satu contoh, Pemerintah Indonesia telah melakukan usaha tersebut dengan meluncurkan berbagai stimulus kebijakan antara lain menerbitkan 16 paket kebijakan yang bertujuan untuk meningkatkan ranking ease of doing business world bank. Stimulus tersebut telah berhasil meningkatkan peringkat Indonesia dari 120 pada tahun 2014 menjadi 72 pada tahun 2017 (Kementerian PPN/Bappenas \& Asian Development Bank, 2019). Pada tahun 2019 Indonesia mendapatkan poin 69,6 masih tertinggal dari Singapura $(86,2)$, Malaysia $(81,5)$, Thailand $(80,1)$ bahkan Vietnam $(69,8)$ (World Bank Group, 2020) namun Indonesia terus menunjukkan perbaikan yang positif setiap tahunnya.

Faktor yang secara umum signifikan mempengaruhi forward participation adalah pendapatan dari sumber daya alam. Sejalan dengan studi oleh Fernandes (Fernandes et al., 2020) yang menyatakan bahwa forward participation banyak dipengaruhi oleh faktor sumber daya alam karena sumber daya alam banyak digunakan sebagai bahan baku untuk proses produksi selanjutnya. Terbukti bahwa negara di kawasan ASEAN yang kaya akan sumber daya seperti Indonesia nilai forward participation nya relatif lebih tinggi dibandingkan negara Thailand dan Vietnam. Ekspor produk primer hasil sumber daya alam memiliki karakteristik khusus, CPO merupakan salah satu produk yang memerlukan penanganan ekstra karena produk turunannya yang beragam, proses pengiriman harus cepat serta harus disimpan dalam gudang yang higienis sehingga menjaga kualitas lebih lama. Jika CPO disimpan dengan sistem pendingin dengan suhu 4-8 derajat Celsius kualitas CPO tetap terjaga dengan baik bahkan setelah 
melewati 12 bulan sedangkan jika disimpan dalam suhu ruang kadar fatty acid dan peroksida lebih tinggi dan akan berpengaruh pada kualitas CPO (Almeida et al., 2019). Sejalan dengan hasil temuan penelitian ini bahwa kualitas infrastruktur yang baik secara positif dan signifikan berhubungan dengan forward participation.

Faktor GDP ternyata berhubungan negatif dan signifikan terhadap partisipasi negara dalam forward participation hal ini menunjukkan permintaan terhadap produk dalam negeri masih tinggi seiring makin tingginya GDP di negara ASEAN 6. Hal ini disebabkan karena konsumsi di negara berkembang masih sangat tinggi sehingga produk belum sempat diekspor sudah terserap oleh masyarakat dan industri seiring dengan pesatnya pertumbuhan industri dan konsumsi rumah tangga dalam negeri. Hal ini juga sejalan jika melihat studi kasus Indonesia, berdasarkan data BPS pada tahun 2019 porsi konsumsi Indonesia dalam struktur GDP mencapai $56,62 \%$. Sehingga pemerintah perlu terus mendorong produktivitas di dalam negeri guna mengkompensasi tingginya permintaan di dalam negeri.

\section{Analisis backward participation}

Pada kedua analisis backward participation, ekspor elektronik dan otomotif pada tahun berjalan serta tahun sebelumnya berpengaruh terhadap backward participation. Hasil positif signifikan lag satu tahun dari dependen variabel untuk semua model menunjukkan aspek dinamis dari variabel tersebut yang berarti tingkat backward participation tahun sebelumnya mempengaruhi partisipasi tahun sekarang. Karakteristik produk yang memiliki backward participation tinggi adalah produk manufaktur dimana penelitian ini menemukan bahwa produk dengan kandungan teknologi menengah dan tinggi berhubungan dengan backward participation secara positif dan signifikan sejalan dengan studi Banerjee (Banerjee \& Zeman, 2020) produktivitas industri teknologi menengah dan tinggi berhubungan dengan partisipasi backward yang menunjukkan bahwa industri manufaktur teknologi sedang dan tinggi tersebut banyak melakukan impor barang antara untuk diproses dan di ekspor kembali. Guna mempertahankan dan mendorong industri tersebut sangat dibutuhkan inovasi yang berkelanjutan namun tentunya biaya juga tinggi. Penelitian ini menemukan bahwa kualitas institusi hukum terhadap perlindungan atas hak kekayaan intelektual berhubungan positif dan signifikan terhadap backward participation. Jika perlindungan hukum atas kekayaan intelektual tidak ditegakkan, industri tidak memiliki insentif untuk melakukan inovasi yang pada akhirnya semakin terputus dari partisipasi dalam GVC.

Negara pada Kawasan ASEAN 6 masih membutuhkan FDI dalam bentuk apapun untuk mendorong perekonomian hal ini dibuktikan dengan positif dan signifikannya tarif terhadap partisipasi GVC backward yang secara tidak langsung dapat diinterpretasikan bahwa penerapan tarif diharapkan dapat meningkatkan FDI. Namun FDI juga perlu untuk ditelaah lebih lanjut karena motif asing sangat beragam antara lain market seeking, resource seeking, efficiency seeking, strategic resource seeking dan network seeking (Dunning \& Lundan, 2008; Hansson \& Hedin, 2007). Aliran FDI positif pada forward participation namun tidak signifikan pada backward participation ini menunjukkan bahwa aliran FDI di ASEAN 6 mayoritas masih bermotif resource seeking dan market seeking karena negara di kawasan ini kaya akan sumber daya alam dan memiliki populasi yang besar, bukan kepada network seeking atau melakukan investasi untuk menjadi pemasok bagi pasar di luar dengan menjadikan negara di ASEAN 6 sebagai basis produksi.

Kualitas institusi pada hal ini institusi keuangan atau jasa finansial untuk pembiayaan dalam negeri negeri positif dan signifikan berhubungan dengan backward participation, hal ini menunjukkan bahwa industri manufaktur dalam negeri dalam melakukan pengembangan industri termasuk ekspor impornya bergantung pada pinjaman dari institusi keuangan di dalam negeri, sehingga intitusi jasa keuangan perlu terus didorong untuk meningkatkan kualitas pembiayaan dan pinjaman untuk tambahan modal kerja guna mendorong keterlibatan industri dalam backward participation. 
GDP pada backward participation juga menunjukkan hubungan yang sama dengan forward participation yaitu negatif dan signifikan hal ini menunjukkan semakin tingginya pendapatan yang ditunjukkan dengan GDP meningkatkan konsumsi produk manufaktur di dalam negeri. Ketika pendapatan konsumen naik, maka mereka yang sebelumnya belum mampu membeli produk otomotif serta produk elektronik seperti televisi, mesin cuci, tentu akan menyerap produk tersebut, produk belum sempat di ekspor sudah lebih dahulu diserap, Asumsi berikutnya adalah walaupun GDP semakin meningkat, industri dalam negeri belum mampu secara efektif melakukan pengolahan bahan baku menjadi barang jadi karena masih rendahnya teknologi yang dimiliki oleh industri pengolahan bahan baku sehingga meningkatnya GDP tidak memberikan pengaruh positif terhadap backward participation.

Agar backward participation dapat terus meningkat Pemerintah perlu mendorong produktivitas industri agar dapat mendorong ekspor karena penelitian ini menemukan bahwa ekspor otomotif dan elektronik positif dan signifikan mempengaruhi backward participation bahwa ekspor otomotif dan elektronik dengan demikian produktivitas industri perlu terus ditingkatkan terutama produk-produk dengan standar ekspor sehingga dapat mengkompensasi dampak dari peningkatan GDP tersebut.

\section{KESIMPULAN dan REKOMENDASI KEBIJAKAN Kesimpulan}

Penelitian ini menemukan bahwa hubungan faktor dalam forward participation dan backward participation terdapat beberapa faktor kesamaan namun mayoritas berbeda. Ekspor produk primer dan manufaktur tahun ini dan tahun sebelumnya serta tingkat partisipasi dari tahun sebelumnya berhubungan dengan forward dan backward participation, Namun ekspor komoditi primer CPO tidak berhubungan dengan forward participation, hal ini diindikasikan bahwa CPO diekspor dalam bentuk barang antara. Karakteristik mayoritas negara pada penelitian ini merupakan negara berkembang dimana semakin tinggi pendapatan meningkatkan konsumsi dalam negeri sehingga faktor GDP berhubungan negatif dan signifikan baik dalam partisipasi forward dan backward sehingga peningkatan produktivitas terutama produk berkualitas dengan orientasi ekspor diperlukan untuk mengkompensasi hal tersebut karena ekspor berhubungan dengan partisipasi GVC.

Faktor pendorong antara forward dan backward participation yang membedakan antara lain hubungan dari investasi asing atau FDI, pada forward participation FDI berhubungan positif dan signifikan sedangkan FDI tidak signifikan dengan backward participation, hal ini menunjukkan bahwa motif asing dalam melakukan FDI di wilayah ASEAN 6 mayoritas lebih kepada resource seeking dan market seeking, belum sebagai basis produksi untuk memasarkan produk ke pasar dunia atau investasi dengan motif network seeking. Perbedaan berikutnya adalah pada forward participation kualitas infrastuktur berhubungan positif karena kualitas produk hasil sumber daya alam berpengaruh dari kualitas infrastruktur salah satunya pergudangan. Sedangkan kualitas pembiayaan dalam negeri dan kualitas institusi perlindungan hukum atas hak kekayaan intelektual berhubungan dengan backward participation. Industri dalam negeri membutuhkan pinjaman modal kerja untuk kegiatan perdagangannya serta perlindungan atas hak kekayaan intelektual menjamin keberlangsungan inovasi industri manufaktur yang dibutuhkan untuk mendorong backward participation.

\section{Rekomendasi Kebijakan}

Dalam usaha meningkatkan forward participation pada sektor industri primer, Pemerintah perlu mendorong produktivitas industri dengan memfasilitasi FDI serta secara berkelanjutan melakukan perbaikan kualitas infrastruktur agar kualitas produk ekspor sumber daya alam semakin terjaga. Lebih lanjut, backward participation di sektor industri manufaktur dapat ditingkatkan diiringi dengan peningkatan produktivitas dan teknologi industri pengolahan di dalam negeri yang didukung dengan kualitas pembiayaan domestik. Kualitas perlindungan terhadap hak atas kekayaan intelektual perlu terus dijaga untuk memberi stimulus industri manufaktur 
menghasilkan inovasi dan menciptakan produk yang berkualitas serta berorientasi ekspor.

Penelitian ini belum memasukkan dampak dari pandemi karena keterbatasan data namun pandemi yang terjadi pada tahun 2020 berdampak pada perlambatan perdagangan internasional termasuk GVC terutama ketika awal pandemi. Sehingga diharapkan ada penelitian lebih lanjut untuk mempertimbangkan faktor peluang dan tantangan terhadap potensi GVC di masa yang akan datang.

\section{REFERENSI}

ADB. (2019). Global Value Chains. In Asian Development Bank and the Islamic Development Bank. https://doi.org/10.5089/9781484392928.001

Almeida, D. T. de, Viana, T. V., Costa, M. M., Silva, C. de S., \& Feitosa, S. (2019). Effects of different storage conditions on the oxidative stability of crude and refined palm oil, olein and stearin (Elaeis guineensis). Food Science and Tehcnology, 39.

Antràs, P. (2020). Conceptual Aspects of Global Value Chains. World Bank Economic Review, $34(3), 551-574$. https://doi.org/10.1093/wber/lhaa006

Arellano, M., \& Bond, S. (1991). Some tests of specification for panel data:monte carlo evidence and an application to employment equations. Review of Economic Studies, 58(2), 277-297. https://doi.org/10.2307/2297968

Baldwin, R. (2016). The Great Convergence. In The Great Convergence. The Belknap Press of Harvard University Press. https://doi.org/10.1142/9789813200586_0009

Banerjee, B., \& Zeman, J. (2020). Determinants of Global Value Chain Participation: Crosscountry Analysis. In World Bank Policy Research Working Paper (Vol. 9197).

Dunning, J. ., \& Lundan, S. . (2008). Multinational Enterprises and the Global Economy (Second Edi). Edward Elgar Publishing Limited.

Fernandes, A., Kee, H. L., \& Winkler, D. (2020). Determinants of Global Value Chain Participation: Cross-Country Evidence. In Determinants of Global Value Chain Participation: Cross-Country Evidence (Issue March). https://doi.org/10.1596/1813-9450-9197

Hansson, A., \& Hedin, K. (2007). Motives for internationalization - Small companies in Swedish incubators and science parks. In Master Thesis. Uppsala University.

Hsiao, C. (2003). Analysis of Panel Data. Cambridge
University Press.

Hummels, D., Ishii, J., \& Yi, K.-M. (2001). The nature and growth of vertical specialization in world trade. Journal of International Economics, $54(1), 75-96$.

Johnson, R. C., \& Noguera, G. (2012). Accounting for intermediates: Production sharing and trade in value added. Journal of International Economics, 86(2), 224-236. https://doi.org/10.1016/j.jinteco.2011.10.003

Kementerian PPN/Bappenas, \& Asian Development Bank. (2019). Policies to Support The Development of indonesia's Manufacturing Sector During 2020-2024 (Issue January 2019).

Kersan-Škabić, I. (2019). The drivers of global value chain (GVC) participation in EU member states. Economic Research-Ekonomska Istrazivanja , 32(1), 1204-1218. https://doi.org/10.1080/1331677X.2019.1629978

Kimura, F. (2019). Production Networks and Unbundling: Reformulating the Conceptual Framework in Theory, Empirics, and Policy Discussion. 98(Icot), 224-230. https://doi.org/10.2991/icot-19.2019.46

Koopman, R., Wang, Z., \& Wei, S.-J. (2012). Estimating domestic content in exports when processing trade is pervasive. Journal of Development Economics, 99(1), 178-189.

Koopman, R., Wang, Z., \& Wei, S.-J. (2014). Tracing Value-Added and Double Counting. American Economic Review, 104 (2), 459-494.

Kowalski, P., Lopez-gonzalez, J., Ragoussis, A., \& Ugarte, C. (2015). Participation of Developing Countries in Global Valve Chains: Implications for OECD Trade Policy Papers No . 179 Participation of Developing Countries in Global Valve Chains. January 2016. https://doi.org/10.1787/5js33lfw0xxn-en

Martínez-Galán, E., \& Fontoura, M. P. (2019). Global value chains and inward foreign direct investment in the 2000s. World Economy, 42(1), 175-196. https://doi.org/10.1111/twec.12660

OECD. (2019). Guide to OECD's Trade in Valve Added (TiVA) Indicators, 2018 edition. https://www.oecd.org/sti/ind/tiva/TiVA2018_In dicators_Guide.pdf

Pahl, S., \& Timmer, M. P. (2020). Do Global Value Chains Enhance Economic Upgrading? A Long View. Journal of Development Studies, 56(9), 1683-1705. https://doi.org/10.1080/00220388.2019.1702159

Taglioni, D., \& Winkler, D. (2016). Making Global Value Chains Work for Development. World Bank Group.

Tinta, A. A. (2017). The determinants of participation in global value chains: The case of ECOWAS. Cogent Economics and Finance, 5(1), 1-14. https://doi.org/10.1080/23322039.2017.1389252 
Trademap. (2021). List of importing markets for a product exported by ASEANMetadata Product: 4001 Natural rubber, balata, guttapercha,...

https://www.trademap.org/Country_SelProduc tCountry_TS.aspx?nvpm=1\%7C\%7C47583\%7C\% 7C\%7C4001\%7C\%7C\%7C4\%7C1\%7C1\%7C2\%7 $\mathrm{C} 2 \% 7 \mathrm{C} 1 \% 7 \mathrm{C} 4 \% 7 \mathrm{C} 1 \% 7 \mathrm{C} 1 \% 7 \mathrm{Cl}$

United States Department of Agriculture. (2021). Oilseeds: World Markets and Trade, Strong Global Consumption Growth in 2021/22 Despite High Prices.

World Bank Group. (2020). Ease of Doing Business rankings. https://www.doingbusiness.org/en/rankings

Xing, Y., \& Detert, N. (2010). Asian Development Bank Institute (Issue 257).

https://doi.org/10.1007/978-1-349-67278-3_116 